\title{
Image and Imagination of the Life Sciences
}

\author{
The Stereomicroscope on the Cusp of Modern Biology
}

\author{
Anna Simon-Stickley
}

\begin{abstract}
The Greenough stereomicroscope, or "Stemi" as it is colloquially known among microscopists, is a stereoscopic binocular instrument yielding three-dimensional depth perception when working with larger microscopic specimens. It has become ubiquitous in laboratory practice since its introduction by the unknown scientist Horatio Saltonstall Greenough in 1892. However, because it enabled new experimental practices rather than new knowledge, it has largely eluded historical and epistemological investigation, even though its design, production, and reception in the scientific community was inextricably connected to the new epistemological ideals of the life sciences caught between natural history and modern science. The development of the microscope will be contextualized within the scientific and technological landscape, showing how Greenough navigated his way through this terrain, and what led him to sow the seeds for the stereoscopic microscope. The historical controversy over the optical mechanism, through which the instrument would generate the desired depth perception, and how this quality was embedded into laboratory practice, will be examined. Subsequently, it will become evident that the specific image of nature produced by the stereoscopic microscope corresponded to the new ideals of the life sciences and their representation.
\end{abstract}

Keywords: Microscopy, Zeiss, Experimental systems, Experimental embryology, Depth perception

Bild und Weltbild der Lebenswissenschaften: Das Stereomikroskop am Scheitelpunkt der modernen Biologie

Das Greenough Stereomikroskop, gemeinhin bekannt als "Stemi”, ist ein stereoskopisches binokulares Laborinstrument, das die Beobachtung größerer mikroskopischer Organismen lebensecht in drei Dimensionen ermöglicht. Seit seiner Einführung durch den damals wie heute wenig bekannten Wissenschaftler Horatio Saltonstall Greenough im Jahre 1892 ist es in der Laborpraxis allgegenwärtig geworden. Da das Instrument jedoch in erster Linie weniger neue Einsichten als vielmehr neue Praktiken ermöglichte, hat es sich seither historisch-epistemologischer Einbettung entzogen, und dies, obwohl die Entwicklung, Produktion und Rezeption des Stereomikroskops in der wissenschaftlichen Gemeinschaft untrennbar mit den neuen epistemologischen Idealen der Lebenswissenschaften im Spannungsfeld zwischen Naturgeschichte und moderner Wissenschaft verbunden ist. Im Folgenden wird die Entwicklung des Mikroskops in den lebenswissenschaftlichen und technologischen Diskursfeldern kontextualisiert und nachgezeichnet, welchen weg sich Greenough durch diese wissenschaftliche Landschaft gebahnt hat. Die historische Kontroverse über den optischen Mechanismus, durch den das Instrument Tiefenwahrnehmung generieren sollte, wird aufgearbeitet. Anschließend wird der Frage nachgegangen, wie sich diese spezielle Visualität in den ersten Jahren des zwanzigsten Jahrhunderts in der lebenswissenschaftlichen Laborpraxis etabliert hat. Dabei wird deutlich, dass das lebensnahe Bild der Natur, welches das Stereomikroskop Wissenschaftler*innen bot, den neuen Idealen der Lebenswissenschaften und seiner Repräsentation entsprach. 


\section{The Stereomicroscope: Where it came From, and Where it went}

In 1892, an unknown American zoologist, Horatio Saltonstall Greenough (1845-1916), wrote to the head of the world's leading manufacturer of optical instruments, Dr. Ernst Abbe (1840-1905) of Zeiss AG in Jena, Germany. Self-confidently he proposed a detailed construction plan for a microscope and accompanying rotator application that would suit his own specific needs, and thus allow for a three-dimensional upright vision when working with specimens. His proposal proved to be successful: the microscope was built and became the first commercially successful stereoscopic microscope, whose design is still employed today.

The Greenough stereomicroscope (Fig. 1), or Stemi as it is commonly known, is firmly established among microscopists, denoting a common build of stereoscopic binocular instruments for observing and dissecting large specimens; one which in more than a century has hardly varied from the originally developed design. Any microscopist will be able to explain to you how its specific set-up enables three-dimensional vision and why the image is neither upside-down nor flipped. Any microscopist will attest that the microscope is ubiquitous in modern laboratories. However, hardly any microscopist will be able to tell you why the microscope was

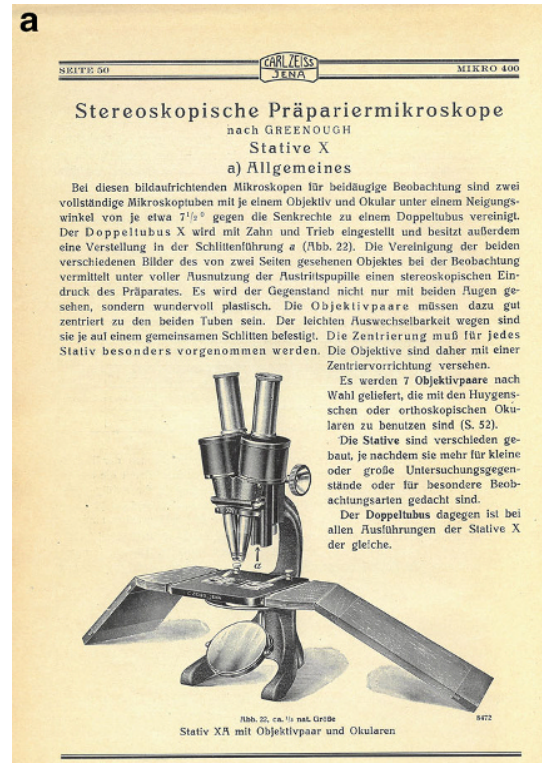

b
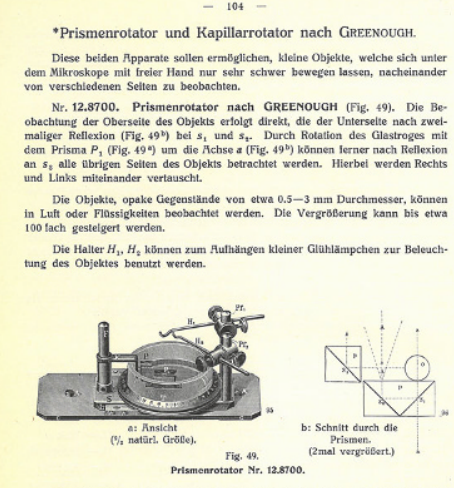

Nr. 12.8702. Prismenrotatos nach GREENOVen Nr. 12.8702. Prismenrotator nach GreENougn mil doppetler Splege
lang der Seilen. Da die Vertauschung van Rechts und Links infolge der einmalijgen Reflexion
$s_{a}$ in manchen Fallon storrend wirken kann, so ist bei dieser Form des an $s_{a}$ in manchen Fallen storend wirken
Apparats durch Hinzuthegung eines
von Rechts und Links beselligt worden.

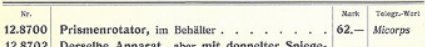

12.8702 Derselbe Apparat, eber mit doppelter Spiege-
lung für die Seitenansicht, im Bethliter

erres

Fig. 1 The Greenough stereomicroscope and rotator application as advertised in the Zeiss catalogue 1927 (Zeiss 1927) 
built in this time and place specifically, or what the underlying epistemological, technological, and individual prerequisites were that concurred towards the end of the nineteenth century. In the following I will answer such questions by contextualising the stereomicroscope within the scientific and technological landscape in which it was conceived, thus showing, how Horatio Saltonstall Greenough navigated this landscape, and what made him lay the groundwork for the stereoscopic microscope. Within this context I will examine the controversy regarding how the instrument was to be built in order to achieve the desired depth perception as well as how this quality was embedded into laboratory practice. Subsequently, will become evident that the specific image of nature produced by the stereoscopic microscope filled a gap between the ideals of the new life sciences and their representation.

The practice of standard monocular microscopy demands disciplining nature's messiness with an arsenal of preparation methods, such as cutting, dying, hardening or fixing, before the instrument will graciously yield an image. Focusing on and magnifying a two-dimensional plane, these impressions of the microscopic world are but highly constructed cut-outs of three-dimensional reality (Rheinberger 2008). Yet in order to be verifiable, microscopic objects did and do need to be rendered durable and the relevant areas to be magnified highly. Thus, significant scientific discoveries are, if at all, associated with the epistemological value (and limitations) of the monocular microscope, while the stereomicroscope and its specific epistemological value has gone all but unnoticed. In this sense, the stereomicroscope resides in the "naturalised background" (Edwards 2003: 185) of the laboratory, so ubiquitous as to become invisible. These "technologies in use", to borrow Edgerton's term, rarely make it to the front pages of our predominantly innovation-centered discipline, though their impact may often surpass flashier instruments of knowledge production (Edgerton 2007). But even focusing on the process of knowledge production, which legitimates much historical investigation of scientific instrumentation, limits historical insight. Instruments are frequently described as mere vehicles to explain the production of knowledge. But, as Espahangizi has suggested, inverting this relationship by explaining technology through scientific knowledge and epistemology, reveals an instrument to be not simply a truth machine, not simply an embodied physical or optical theory, but also a thinking medium-a medium shaping understanding (Espahangizi 2011: 29). The stereomicroscope is such a medium: the image of nature it creates entered scientific reasoning and understanding to depict the new epistemological ideals of the life sciences. ${ }^{1}$

Charles Darwin, and Lamarck before him, sent biology on the mission to explore the evolution of species throughout the millennia. Natural his- 
tory was essentially just that-a historical discipline, employing historical methodology. Greenough and his fellow biologists, however, were witnessing a marked change in this methodology and research interest, away from the comparative, descriptive and frequently speculative approach of natural history, and towards the physiological approach of the medical disciplines. Setting the life sciences on the same scientific footing as physics and chemistry entailed implementing a mechanist approach to the processes of life and experimental methodology. ${ }^{2}$ Experimentation in turn entailed working with live organisms and understanding not only their relationship to their natural environment but also how they worked as a whole system. In the wake of the experimental turn, precision instrumentation became essential not only to the medical, physical, and chemical disciplines, but increasingly to the biological sciences too. Cultivating close ties to the universities, Zeiss had advanced in preceding years to the top of Europe's optical industry by transforming a manual craft into a mathematised science. It was their optical ingenuity that facilitated the improvement and introduction of Greenough's stereomicroscope onto the world market and into laboratories across the globe.

Thus, tracing the trajectory of the stereomicroscope, from its origins in the historical and epistemological landscape, navigated by the techno-scientific polymath Greenough, is following one thread through the complex tangled web of fin de siècle biology on the cusp of modern science-one which, when unraveled, proves to be tangential to some of the major scientific and philosophical challenges of the day.

\section{The End of Morphology}

The earthquake that shook the life sciences in the mid-nineteenth century had been Darwin's theory of evolution and the ripples it sent down biology's core were to be observed well into the 1880s and 1890s. For nearly four decades after the publication of the Origin of Species, phylogeny stayed enormously popular and the search for the origins of all sorts of species was promoted on a large-scale by natural historians in Europe and the USA. Nearly all various sub-disciplines of the life sciences, apart from physiology and biochemistry, provided proof supporting the umbrella of Darwin's theory, which in the next decades was put at the service of finding further evidence (Jahn 2004; Nyhart 2009). Morphology, the study of structures such as limbs and bones and less of their functions, was especially prone to expanding the evidential basis of the theory of evolution, as Darwin had himself emphasized in 1859, "the most interesting department of natural 
history is morphology and may be said to be its very soul." (Darwin 1988 [1859]: 198).

Ernst Haeckel (1834-1919), University of Jena's famous flamboyant morphologist, was a lifelong committed and at times overzealous Darwinist. He added embryology to the set of disciplines supporting evolutionary theory by formulating his biogenetic law-marking Jena as the epicenter of evolutionary morphology (Gould 1977; Nyhart 2002). This influential theory, variations of which had circulated for decades in romantically inclined research programs, stated that the stages an embryo passes through while growing limbs and organs are parallel to the stages adult specimens of the species have traversed throughout their phylogenetic history. Observing embryogenesis was, thus, observing evolution in action. Such analogy between micro-and macrocosm was no vulgar vitalist Naturphilosophie anymore, for with the advent of Darwinism nature could once again be seen as one, its specific phenomena being interwoven by the same unifying principle (Kleeberg 2007: 202). This principle, evolution by natural selection, regulated and generated all possible forms from the universal to the particular, from the primordial sphere (cells, microorganisms) to the manifold complex beings found in nature. Hence the original form, the sphere, was regarded as the archetypical form of nature. In this context the spherical stereometric shape gained new currency in Jena not only for its sublime harmonious symmetry (as depicted in the popular booklets Kunstformen der Natur), but for the universal principle it represented (Kleeberg 2005: 130-143).

But by the early 1880 s and throughout the 1890 s, it seemed to some that morphology had done all it could in service of phylogeny; nothing new could be gleaned from more meticulous descriptions of specimens that were dead, fossilized or prepared beyond recognition and speculating on their ideal ancestral archetypes. Exasperated and unsatisfied with morphology's speculative results, naturalists appropriated physiology's mechanical, experimental approach that promised objective, testable, "scientific" truths (Hopwood 1999), ${ }^{3}$ in what Allen has controversially called the "revolt from morphology" (Allen 1981; Nyhart 2002). ${ }^{4}$ Increasingly, a shift set in that altered the face of the life sciences.

\section{The Mechanist Conviction and Visual Holism}

One of the first proponents of this new physiological approach to life was Wilhelm His (1831-1904) (Hopwood 1999). In contrast to evolutionary morphologists caught in a Darwinian quest to understand form through 
evolution, physiologists sought to understand the physical and chemical forces that directed the processes within a living being. Embryology, like no other discipline, became the arena in which on the one hand holistic and vitalist philosophies and on the other hand mechanistic explanations were debated (Allen 2005). A fierce critic of Haeckel and his disciples in Jena, Wilhelm His tried to show that it was differential growth and the physical pressures and pulls this created, that forced developing tissue to grow in a certain way (Hopwood 1999). To demonstrate his mechanist conviction, he imitated embryogenesis by, for example, bending and twisting a rubber tube representing a malleable nervous system. Yet these models only ever displayed single organs. His was convinced, however, that to truly appreciate the mechanical formation of embryos a zoologist must be able to understand how the embryo worked as a whole, to visualise it spatially (Hopwood 1999). For quite different reasons than Haeckel, His too assigned the holistic three-dimensional shape special status. For their presentation His devised a method of reconstructing embryos from impossibly fine slices, cut with an instrument he invented, the microtome. It allowed him to make a series of sections, which fit perfectly together when scaled and transferred to wax. This process of modelling, according to His, would cultivate a mechanical worldview within his students (Hopwood 1999). Understanding the whole form of the developing embryo was, as His advocated, fundamental to the new physiological approach to the life sciences and commercially available embryological models became increasingly popular throughout the 1880 s and 1890 s.

What had led to zoological microscopists spatio-visual impoverishment, His admitted self-consciously, was a fixation on minute structures, such as the inner workings of the cell (Rheinberger 2008: 5), influenced by the laboratory technologies of the time, namely microscope and microtome (Hopwood 1999: 476). Throughout the nineteenth century the magnifying power of microscopes had increased substantially so that it was possible to focus on ever more intricate objects, dissected to reveal their innards. In order to maximize magnification, these monocular instruments reduce nature to two dimensions. This plane is the intersection where nature and its mode of representation are intertwined and "engage in mutual interaction. Here, at the very point of magnification, the decision is made about the way in which the specimen will enter into the picture" (Rheinberger 2008: 6). What is being created at the focal point of the microscope is the visual imaginary of science.

And what was being created in the wake of the microtome was, as E. S. Russell (1887-1956) lamented, "an evil heritage of detailed and unintelligent work" (Russel 1916: 268), which would result in researchers knowing "only cross-sections and stained tissues, but neither whole animals nor 
their mode of life!" (Haeckel 1881 in Uschmann 1983: 158). Their arsenal of preparation techniques, from chemical baths to microtome cuts, blurred fact from artefact so that it was not necessarily clear what was being depicted, "the object itself or the means of its objectification" (Rheinberger 2008: 6). A new sense of objectivity entered the life sciences, associated not only with testable hypotheses and replicability, but also with visual language. Whereas Haeckel was recycling romantic notions of ideal spherical shapes, the new generation of experimentalists developed new standards for truth in visual representation. Photography set these standards and promised scientists an exact imprint of nature onto the photographic plate; a naturalistic depiction free from the meddling minds of scientists and their encroaching archetypes projected indiscriminately onto nature's images (Daston \& Galison 1992; Daston \& Galison 2007; Kleeberg 2007). The microscopist's laboratory was increasingly suspected of abstracting so far from nature as to yield either only descriptive or, worse, speculative results where dogmatic adherence to metaphysical principles filled the gaps left by the lack of empirical results, and a too narrow visual appreciation of specimens. The solution to the immanent collapse of microscopic morphology was, as Kohler has pointed out, "to retrieve elements of the older natural history: its comprehensiveness and breadth of vision; its concern with the entire life histories of plants and animals, and their relations to their environments", to re-naturalize the lab (Kohler 2002: 475). Life would be brought back into the life sciences and, as we shall see, so would be the sphere.

\section{The Experimental Turn}

In order to study live animals, aquaria and vivaria were integrated into laboratory environments and marine stations were set up along the European and North American coasts to satisfy the new demand for fresh organisms (Kohler 2002). Controlling the environmental variables within the reconstructed natures of aquaria, vivaria, and petri dishes not only contributed to scientists' understanding of what environmental influences affect organisms' healthy development, but also provided the material means to systematically intervene into living tissue (Reiß 2012). Intervention into aquatic invertebrate embryos was especially easy, as their systems are substantially simpler than vertebrates' (Hopwood 2011), and growth naturally takes places in the open water as opposed to within a mother animal (Hopwood 1999: 493). 
Thus, the experiment unified the epistemological debates within the life sciences, the mechanical versus the holistic philosophy of life, the use of dead, sliced and highly manipulated specimens versus working with whole, living organisms. Experimentation, declared the mechanical biologists, would enable them to distinguish between hypotheses. Theories inaccessible to experimental testing, like the one that there existed a nonchemical, non-physical "vital" force, which shaped organisms according to an ideal plan, were worthless, or, simply not a matter of science (Allen 2005: 266). Experimentation entailed at least a pragmatic mechanist view, if not a full commitment to the mechanistic philosophy, for experimentation can only prove mechanisms. Naturally experiments were only possible with live organisms, at least at the beginning of the investigation. ${ }^{5}$ Thus, re-naturalising the laboratory with live organisms, appreciating their entire form as well as their life cycle was imperative to the new experimental ideal. In these experimental knowledge systems, technology, and nature were tightly interwoven (Reiß 2012), and a microscope that allowed scientists to bring nature even closer, straight from the sea onto the vivisection table, imprinting it upon the observer's retina, was at once born from and facilitated the new experimental ideal.

Born and bred in Jena, zoologist Wilhelm Roux (1850-1924) became the pioneer of experimental embryology (Sander 1997: 2; Hopwood 2011: 10). Originally a student of Haeckel at the University of Jena, Roux soon grew tired of forcing embryogenesis into Haeckel's recapitulation theory, "confidently assuming that positive rewards would come with incorporation of such information into a sweeping conception of ancestral-embryonic parallelism" (Coleman 1977: 53). Roux, the "apostate student" (Gould 1977: 194), was convinced that embryology should search for causation via experiment, and that clearly defined hypotheses should be guiding these experiments (Nyhart 1995: 289-290). By controlled manipulation of environmental conditions, such as mechanical or chemical disturbance of egg and embryo, variations of light, temperature, pressure, or orientation in the gravitational or electromagnetic field, embryologists could directly observe what influenced the developing organism and how changes happened (Sander 1997; Hopwood 1999: 10) This research program, which Roux called Entwicklungsmechanik (developmental mechanics), though influenced by His' mechanist conception of formation, understood embryological mechanics not simply as the somewhat crude interplay of pressures and pulls but more generally as a Kantian commitment to causal explanation (Hopwood 1999: 493). Therefore, and to His' dismay, Roux did not take on his lead of modelling to understand the interaction of forces, nor was he particularly concerned about the spatial appreciation of his embryos. He made do with the instrumentation he had come to know. Entwicklungsmechanik, 
institutionalized within the University of Jena and equipped with its own scientific journal, laid the foundations for the rush of experimental activity that began in the 1880s in embryology (Jahn 2004: 429). Thus, the epistemological debates in the life sciences between stereometric representations of evolutionary unity and mechanist models, between evolutionary idealism and physiological experimentalism, were taking place directly in the intellectual front yard of the Zeiss company.

\section{Jena at the Junction of Science and Technology}

Setting the stage for production of the Greenough stereomicroscope was the city of Jena, a major junction between the university, scientific research, and fine mechanics manufacturers such as the optical workshop of Carl Zeiss (1816-1888), whose enterprise, the Carl Zeiss AG, had risen to the top of the optical industry by the time Greenough's draft landed in the company's postbox. ${ }^{6}$ From its inception Zeiss had been the university's instrument workshop (Wimmer 2005: 61-62), and its later success was decisively influenced by scientific research. Transformed from an economically limited sector based for decades on traditional trial-and error methods, the production of optical lenses turned into a precise technology generating some of the world's leading microscopes at the time. This was in large part due to the scientific work of Ernst Abbe (1840-1905), who became a physics lecturer at Jena University in 1863 where he set about equipping his department with physical instruments for teaching and research (Wimmer 2005: 63). Optical lenses became his specialization and supplementing his research with Carl Zeiss' optical lenses allowed him to publish his theory of optics, Contribution to the Theory of the Microscope and of Microscopic Perception (Abbe 1873). There Abbe established that greater resolution required lenses of large aperture and the use of oblique illumination, which enabled Zeiss henceforth to manufacture lenses directly according to a mathematical design, instead of cutting and sanding the glasses until they fit the purpose (Abbe 1873). Abbe was made partner in 1876. Thus, the decisive factor for Zeiss to become a global player in optical science technology was its interdisciplinary relationship to the scientists of the University of Jena.

As partner, Abbe himself established another scientific cooperation to overcome the technical problem of chromatic aberration. The composition of the glass then used for optical lenses failed to disperse light rays correctly, resulting in a colourful fringe around the edge of the microscopic image. In 1879 Abbe received a letter accompanied by a glass sample from 
the glass technologist Otto Schott (1851-1935), who had received his doctorate in glass chemistry at the University of Jena. This new lithium-based glass composition seemed promising in solving the afore-mentioned problem (Steiner 2001). ${ }^{7}$ Together with the Prussian government Zeiss acquired land and financed the building of a laboratory where Schott conducted his experiments. Within short time, Schott was producing over eighty types of glass for Zeiss, all of which met the specifications of Abbe's optical theory and became the standard for laboratory glassware in Germany (Espahangizi 2011: 33; Cahan 1989: 15). His borosilicate glasses were especially groundbreaking, opening up new possibilities for optical precision and durability. It was these improved glass-making skills, which facilitated the production of the special prisms later installed in the stereomicroscope. Furthermore, the success of absorbing and working with unsolicited input from non-affiliated scientists like Otto Schott impelled them to consider Greenough's proposal. But even so, Zeiss, for all the optical feasibility and their openmindedness towards unsolicited proposals, would not have accommodated the personal fancy of one individual scientist.

In the intervening years, however, the life sciences had transformed, a transformation that had been determined to a large extent, in Jena, the city in which Abbe and his right hand, physicist and optician Siegfried Czapski (1861-1907) worked. Personal contact with Jena's scientists was routine and Czapski, who had since 1891 taken on many of Abbe's responsibilities as a managing director of Zeiss, continued the tradition of working in close collaboration with the university. Throughout his life Czapski maintained a close relationship with the zoologist Anton Dohrn (1840-1909), who developed and expanded the marine observatory in Naples, which he equipped with the latest Zeiss instruments (Carl Zeiss AG 2005: 26-29). In a letter to Dohrn Czapski recounts that he had handpicked a whole team of scientists for the firm including mathematicians, physicists as well as astronomers, biologists, and chemists, "fast alle habe ich ausgewählt", Czapski proudly stressed (Flitner \& Wittig 2000: 54).

By this time, Abbe had set up a foundation honoring the work of his late business partner Carl Zeiss with the objective of funding scientific research at the university as well as supplying instruments (and prototypes) for laboratory testing (Wimmer 2005: 63). Indeed, it was only after the microscope's efficacy had been confirmed by Leo Drüner (1870-1940) and Hermann Braus (1868-1924) at the University of Jena that Zeiss finally initiated serial production (Gerlach 2009: 750; Drüner \& Braus 1895). Czapski was, thus, well aware of the latest developments towards experimentation on live animals and the visual holism this entailed. From the specific node between science and technology that Zeiss inhabited in the intellectual 
landscape of nineteenth century Germany, they could witness the shifting ideals of the life sciences that were digging up the epistemological terrain.

\section{Horatio Saltonstall Greenough}

When Horatio Saltonstall Greenough's letter arrived in Jena in 1892 nobody at Zeiss or even at the university was familiar with this obscure scientist. And to this day, though his microscope is ubiquitous, the man himself is largely forgotten even among microscopists. And the few historians who have studied him neglected to go beyond biographical fragments and describing Greenough's involvement with Zeiss. ${ }^{8}$ By highlighting some of these fragments and contextualising his work into the larger history of science and historical epistemology Greenough's place in the development of the life sciences will become evident.

Born into an upper-middle class American family in 1845, Greenough grew up in Cambridge, Massachusetts, surrounded by the intellectual elites at Harvard, whom his parents liked to entertain (Lau \& Kreindler 2018: 14, Wright 1972). ${ }^{9}$ A famous sculptor and inventor of the phrase "form follows function", his father, Horatio Greenough Sr. (1805-1852), was actively involved in the academic and cultural life of the town, and actively advanced his son's education, who at the time seems not to have been overly grateful for that: art historical biographies about Greenough Sr. suggest his son was a rather spoilt child; he was "the most disagreeable child I have ever seen [...] and I fear will prove a source of trouble to his parents" wrote his aunt, who felt reminded of royal children, describing him as "wilful and noisy" (Wright 1963: 257). Sadly, Horatio Greenough Sr. passed away before his son was seven years old, and in her grief his mother renamed her son, who had thus far been called Henry, Horatio. From then on, Greenough would carry the name of his famous father, and with it a constant reminder of his heritage. Growing up in Boston, the city where everyone knew his father and his great George Washington statue in front of the Capitol Building, Greenough quite possibly felt inadequate compared to his father's fame and fortune. Caught between not having to make a living and wanting to leave a mark on the world, Greenough decided to become a "man of science" (Greenough 1902 in Betriebsarchiv Carl Zeiss (BACZ) 1900-1906: 1576/76). ${ }^{10}$ Letters from Greenough to the naturalist Louis Agassiz and the mathematician Benjamin Peirce as well as the crocodile he shot and donated to the Boston Society for Natural History, demonstrate the continued relationship he maintained to academia (Agassiz 1885; Lau \& Kreindler 2018; and Boston Society for Natural History 1872: 175). So, after giving 
up his somewhat arbitrary career choice of real-estate salesman and abandoning his randomly chosen courses at MIT without a degree, ${ }^{11}$ Greenough travelled to Paris to become an embryologist. ${ }^{12}$

\section{Greenough's Place in the History of Science}

Although his scientific achievement was never formally acknowledged with a degree, Greenough evidently felt qualified enough to contribute to the science of the day. Notwithstanding that his first published article, printed in The American Naturalist in 1886, seems like a half-hearted exercise in descriptive natural history, ${ }^{13}$ a year later he was already working alongside leading French embryologists at the marine laboratory at Concarneau on the Breton coast. ${ }^{14}$ Here Greenough was able to conduct his first own experiments on the larval stages of marine invertebrates, which he published in 1891 (Observations sur les larves d'oursin) and 1892 (Sur les homologies des premières stades suivant la segmentation chez les batraciens) in the Bulletin de la Société Zoologique de France, of which he had become a member in 1888 (Greenough 1891; Greenough 1892).

Having progressed to research objects that demanded quite a bit more more scientific knowledge, vocabulary, and experimental dexterity (such as delicate eggs, embryos and larvae) his subsequent work differed vitally in academic style and expertise from his previous work. While both of his published experiments in 1891 and 1892 are still descriptive and do not display Roux' new interventionist experimentalism, they do reveal Greenough's experimental dexterity, exercised through a range of scientific instruments and the schooled vision of a scientist-skills that lead him to realize the drawbacks of his instrumentation. In his 1892 paper, Sur les homologies des premières stades suivant la segmentation chez les batraciens, for example, he compared the gastrulation of peripatuses, a type of marine velvet worm with that of amphibians, a process that was largely misinterpreted in the nineteenth century (Sander \& Ohly 1999: 247-248; Greenough 1892). ${ }^{15}$ His results, however, merely confirm what had been observed by other scientists on other organisms, though without inferring a possible phylogenetic connection and his causal analysis is fragmentary (Greenough 1892: 57-59; Sander \& Ohly 1999: 247-248). ${ }^{16}$ Whatever scientific results he had delivered, they were based on a misinterpretation of amphibian embryogenesis ${ }^{17}$ and became redundant upon correction in the early twentieth century. The historiographical tendency of focusing on the progression of science, on scientists who produce new knowledge instead of new practices has, it seems, obscured Greenough from historical 
recognition. The topos of the forgotten scientist, brilliant but ahead of his time and hence unappreciated by the scientific community is, thus, not accurate. My research did not procure any further footprints of Greenough in the scientific landscape, despite his evident connection to the learned centers in the USA, France and Germany. So, despite his claims of being a "man of science" (Greenough 1902 in BACZ 1900-1907: 1576/76), Greenough's lasting contribution to science was not new knowledge but rather new practices. In this respect the few publications he published do, however, contain valuable information about the process that sparked his idea for a microscope with three-dimensional projection. Given the haphazard results of his second paper, he does not miss the opportunity to praise his instrumental set-up, implemented to study the sea urchin larvae. Having first prepared them with the dye ("brun de Bismarck"), he had then proceeded to place them under the microscope employing special instrumentation to rotate and view the specimens from all sides (Greenough 1891: 239). This special instrumentation, he states in the first paragraph, was a method devised by the assistant director of the Station biologique de Concarneau, Laurent Chabry (1855-1894), a protagonist of nineteenth century developmental biology.

\section{The Influence of Laurent Chabry}

Having obtained his PhD in medicine (1881), Chabry's medical background led him to become one of the first biologists in France to use surgical experiments to manipulate blastomeres of marine invertebrates to create "heremetiques" (Chabry 1887), thereby delivering valuable information on the mechanics of cell differentiation in early embryonic stages. Like Roux in Jena, Chabry's conception of mechanics did not denote a branch of physics but rather a Kantian understanding of natural causality, ${ }^{18}$ that is, the causes for the formation of organs, which cells grow into which organs, and what causes the differentiation of unspecified cells. Inspired by C. H. Georges Pouchet (1833-1894), French naturalist and director of the marine station at Concarneau, to investigate cellular mechanics of embryos, Chabry's subsequent thesis of 1887 also betrays Étienne Jules Marey's (1830-1904) influence on his methodology. Having visited Marey's lectures at the Collège de France in Paris (Fischer 1991: 35), Chabry had obviously adopted his teacher's view on experimentation: "The experimenter must know at every instant how to modify the instruments that he uses and often how to manufacture them himself" (Fischer 1991: 12; Marey 1878). 
In 1884 Laurent Chabry had started a series of experiments on cellular mechanics of the embryonic Ascidia aspersa, a type of invertebrate marine creature that feeds on plankton and lives on the sea bed. To handle them correctly during his experiments he had invented special instrumentation for use under the microscope (Sander \& Fischer 1992: 191). It is this "technique nouvelle dont la partie essentielle [est] due à M. le Dr Chabry" to which Greenough refers in his article, and which is the direct conceptual precursor to the stereoscopic microscope and its rotator that Greenough would himself design a year later. Chabry's so-called capillaires porte d'objet, to which a perforateur needle was added for piercing embryos, allowed him to pick out individual embryos, orient and rotate them to see his specimens from all sides and then pierce individual cells of the blastomere at the two- or four-cell phases, without inhibiting development. Chabry's complex set-up of micro-tools, the explanation of which took up half of his doctoral thesis, and can only be briefly outlined here, consisted of a long L-shaped capillary into which a pipette with an attached syringe containing the cells could be slid (Chabry 1887). Via capillary action and a system of pressure valves, Chabry could exercise very fine control over the blastomeres and pierce them without harming, in order to prevent further development. For the perforator needles he had experimented with natural materials, such as insect pins, but in the end settled for glass lances that he made himself by heating a fine glass filament on a red-hot platinum plate until plastic and in the right moment whisking it to produce a short, rigid, and incredibly fine needle point (Sander \& Fischer 1992: 192). It was Chabry's technical knowledge and crafting skills that led him to take instrumental shortcomings into his own hands and start bridging the gap between science and precision technology, an objective Greenough adopted himself. Greenough apparently greatly appreciated his colleague's experimental virtuosity and welcomed the new possibility for three-dimensional vision:

La méthode d'observation que j'ai employée me permettant d'obtenir rapidement des rotations autour d'un axe horizontal sous le microscope, offre le moyen de déterminer la forme d'un objet détaché ou isolé et les rapports de ses différentes parties, mieux que ne le donne l'examen microscopique ordinaire. (Greenough 1891: 239)

So impressed must Greenough have been with Chabry's capillary rotating device that he had a similar rotating device produced by Zeiss along with the stereoscopic microscope (Fig. 1). This has been briefly noted by Sander (Sander 1992: 239), though it seems that Chabry not only influenced Greenough's practical instrumentation plans, but also fostered his appreciation of three-dimensional, naturalistic handling of specimens, and 
introduced him to experimental embryology in the first place. Without this acquaintance it would be difficult to explain why Greenough would have fused his broad knowledge base with Chabry's experimental inventiveness. What Chabry achieved mechanically, Greenough sought to achieve through sophisticated optics-three-dimensional, life-like viewing beneath the microscope.

\section{Binocularity and Stereopsis}

In designing his plan for a stereoscopic microscope, Horatio S. Greenough would have drawn on new insights into the nature of human vision in the nineteenth century. While binocular vision was for most of human history considered to be somewhat of a biological extravagance (much in the same way as wisdom teethin case one should be lost during the struggle for survival, Wade \& Ono 2012: 55), the connection between retinal disparity and depth perception was not established until the discovery of perspective made studying ancient theories of vision and visual depth imperative. Leonardo da Vinci (1452-1519), for example, studied Euclidian geometry and became a central proponent of binocular superiority: "Things seen with both eyes will seem rounder than those seen with one eye." 19

Had da Vinci studied geometric objects instead of spheres, he might have been able to explain the purpose of retinal disparity, as Charles Wheatstone (1802-1875) lamented in his 1838 publication, which finally established the reason for spatial depth perception (Wheatstone 1838). Originally a physicist and instrument maker, Wheatstone had ventured into optics, wondering how the brain produced a three-dimensional, seemingly solid world while humans could only reproduce two-dimensional images of it. Movement and angles did not seem like satisfactory answers. In his treatise on stereopsis he elaborates his findings:

[...] the projection of two obviously dissimilar pictures on the two retinae when a single object is viewed, while the optic axis converge, must therefore be regarded as a new fact in the theory of vision. It being thus established that the mind perceives an object of three dimension by means of the two dissimilar pictures projected by it on the two retinae, the following question occurs: What would the effect of simultaneously presenting to each eye, instead of the object itself, its projection on a plane surface as it appears to that eye? (Wheatstone 1838: 372-373) 
Driven by this question he had built the first stereoscope ${ }^{20}$ and throughout the nineteenth century stereoscopic photographs, especially of sculptural art works, became wildly popular (Pellerin \& May 2014). Despite this success, Wheatstone could not get any British microscope manufacturer to build him a stereoscopic microscope in the 1840s (Gerlach 2009: 740). Nobody, neither scientists nor wealthy laymen seeking to entertain their guests, needed a microscope that accomplished only slightly more than a magnifying glass.

This is not to imply that there had not been stereoscopic microscopes before, or that Greenough was a genius inventor-scientist, who built his design on nothing but the new and improved theory of visual depth perception. Binocular microscopes and monocular dissecting microscopes had been built since the seventeenth century, but none of them displayed all the specific characteristics of a truly stereoscopic microscope, that is: 1. delivering one image to each eye (binocularity), 2. each of which is erect and unreversed, 3. their angles differ slightly, so that upon combination the brain perceives depth and three-dimensional structure (stereopsis) (Greiner \& Sander 1987: 162-163).

One might add that stereoscopic microscopes never magnify very strongly as depth perception is then lost.

Chérubin d'Orleans (1613-1697), a Capuchin monk who was a natural philosopher at Louis XIV's court in Versailles, is credited with having built the first microscope in 1671 that fulfilled the above-mentioned three characteristics (Gerlach 2009: 737-738). In Johann Samuel Traugott Gehler's Physikalisches Wörterbuch (Gehler 1787) the d'Orléans' microscope is praised for its lifelikeness: "Beim Gebrauch beider Augen sahe man die Gegenstände näher und lebhafter, und glaubte sich gleichsam mehr in die Scene, die man übersah, hinein versetzt" (Gehler 1787: 357). The image displayed the three-dimensional effect of stereopsis, however, instead of rendering the image stereoscopic, the d'Orléans microscope presented the object under scrutiny as pseudoscopic: an indentation would appear like an elevation (Greiner \& Sander 1987: 162-163). Apart from this visual inconvenience, the instrument, which consisted of two identical tubes inclined towards each other and coming together in a set of objectives ground so they could be connected at the tip of the microscope (Fig. 2), could not be adjusted for different viewers (Gerlach 2009: 738). Furthermore, the focal distance was too long to enable any magnifications above a few times the original size and Gehler's Physikalisches Wörterbuch reported it being inconvenient for longer use, "die Vortheile, die solche Instrumente in Absicht auf Lebhaftigkeit des Bilds so gewährleisten, hoben sich gegen die Unbequemlichkeit des Stellens wieder auf" (Gehler 1787: 357). 

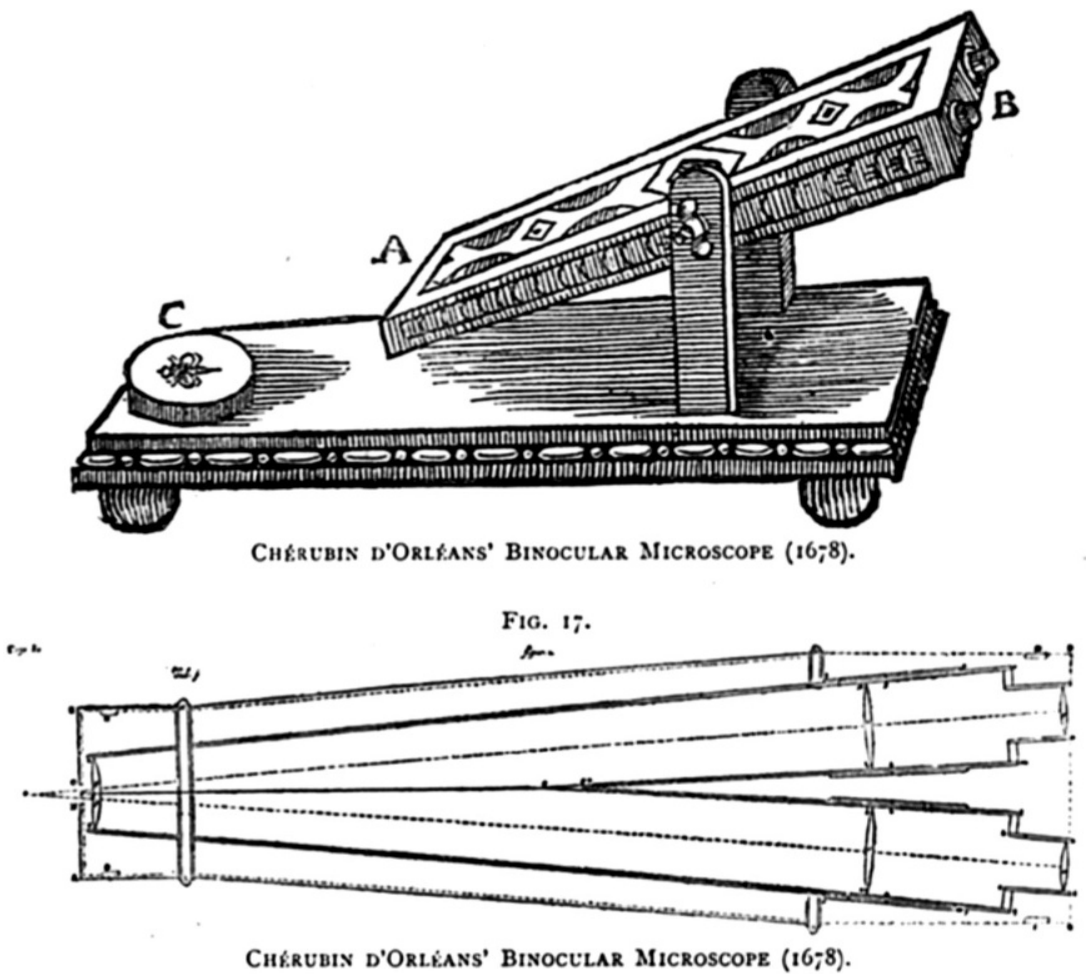

Fig. 2 The first binocular microscope was built by Cherubin d'Orleans in 1678 (Mayall 1886: 1014)

When Wheatstone discovered the reason for depth perception, interest in binocular microscopes was rekindled, and in the mid-nineteenth century Dutch scientist Pieter Harting (1812-1885) attempted to make d'Orléans' model work (Harting 1859: 242-243). ${ }^{21}$ Even so, it would not satisfy the growing desire within the scientific community for greater magnification, which could only be achieved with larger numerical apertures of the objective lens, leading to shorter working distances (Gerlach 2009: 740). The solution was to use only one objective at the tip of the microscope and split the incoming light behind the objective lens through prisms. Thus, John Leonard Riddel managed to achieve a binocular, even stereoscopic, microscope in 1853 (West 1891: 57). However, several optical deficiencies hindered it from becoming widely available: besides strong spherical and chromatic aberrations it was moreover still not capable of achieving high magnifications without aggravating the imperfections. ${ }^{22}$ Thus, in scientific practice binocular microscopes were nearly never better than their monocular counterparts, as Ernst Abbe, head of the Zeiss optical works in Jena, put it in 1880: “[...] bei den meistverbreiteten Binocu- 
lareinrichtungen [bleibt] ein befriedigender Gebrauch auf ziemlich geringe Vergrösserungen beschränkt [...] und [verspricht] deshalb auf vielen Gebieten des mikroskopischen Studiums gar keinen oder nur gelegentlichen Nutzen" (Abbe 1904 [1880]). ${ }^{23}$ Greenough did not agree.

\section{Greenough's Design for an Orthomorphic Microscope}

In order to study the minute structures of organisms, prepared and sectioned into two-dimensional imprints of themselves, only a highly magnifying microscope would do. But, as we have seen, Greenough, Chabry as well as the experimentalists surrounding Wilhelm Roux were not just examining far larger objects, living eggs and embryos, they were also manipulating them and staging artificial environments to find out what forces cause development (Fig. 3). How could Greenough reasonably handle his specimens without killing them, when available microscopes would warp the image of the object and his instruments, so that they appeared on their head, reversed, and without any natural relief indicating their depth and solidity. Frustrated with such abstractions, Greenough longed for a microscope with which he would be able to comfortably dissect his specimens. This was understandably difficult when his hands were not doing what his eyes told him.

His background in the living rooms and lecture halls of Harvard professors provided Greenough with basic knowledge of optics and the necessary self-assurance to approach the head of Zeiss in Jena suggesting that they build him an "orthomorphic" microscope. In his first letter to Zeiss, dating to 1892, Greenough drew out a detailed plan of his microscope design, complete with the physical specifications, as seen in Fig. 4 (BACZ 1897-1898: 1579/1). ${ }^{24}$ The light beams would be separately magnified by two objectives and would then travel along two separate tubes, each beam traversing a lens to erect, that is, re-inverse the flipped image, and an ocular, to further multiply the magnification before hitting the retina (Gerlach 2009). According to him, this design would create an upright, unreversed and most importantly, in his own words "orthomorphic" image. Greenough defined orthomorphic vision as "that special case of stereoscopic vision which corresponds to the determination of a solid detached object by two of its central projections: so that the ratio of the 'field' [width of the image] to 'depth' is seen at its true value." (Greenough 1896 in BACZ 1897-1898: $1579 / 1){ }^{25}$ Originally the term was borrowed from cartography, where it characterizes a map projection, in which an angle on earth is preserved in 
are specially, mites to showing the demonthatise honer af the cafleary notatina amp watras; there prefurations are of a stage isctermediate between the gastivila of the Qhatend. The anneared elletches

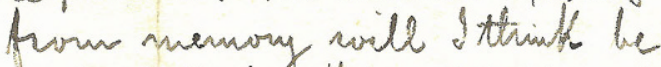

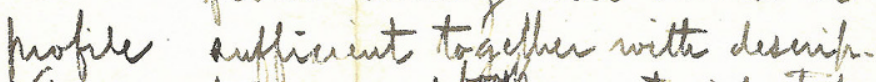

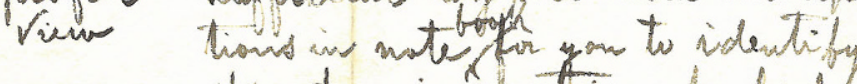
the stap in queation of which funtal true are sertral toter of prefparations.. It avould sttinath he - avial ueful beticles the taree 6oley vivar princiffal vienos here annereed Le cutul. to chow some afligine vienes of the same atruge wistte istations notes. In conchucion of will ouly add that the preforationas ane entrely at yover disposal to use af your own t if you chem it inerefechient to have drawings made tam Frgat at all cavions that you chould do so on

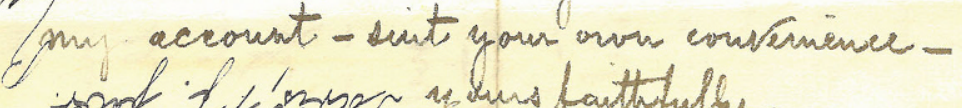

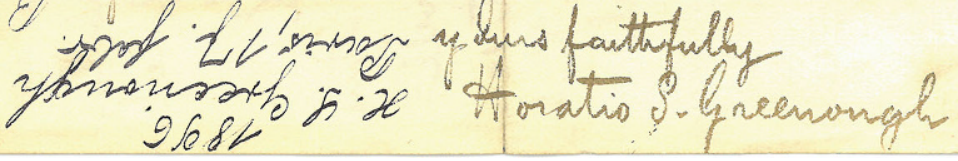

Fig. 3 Greenough's sketches of sea urchin embryogenesis from a letter to Czapski dated 1896 (Zeiss Archive (BACZ) 1892-1896: 1578/95)

the map. Thus, the magnification of the object should be identical in all three dimensions.

The foundation for Greenough's three-dimensional design preserving correct dimensions and orientation was provided by two separate channels of vision leading to each eye, as established by Wheatstone sixty years before. While in preceding years stereoscopic microscopes had sought to maximize magnification by splitting the incoming light behind the main 


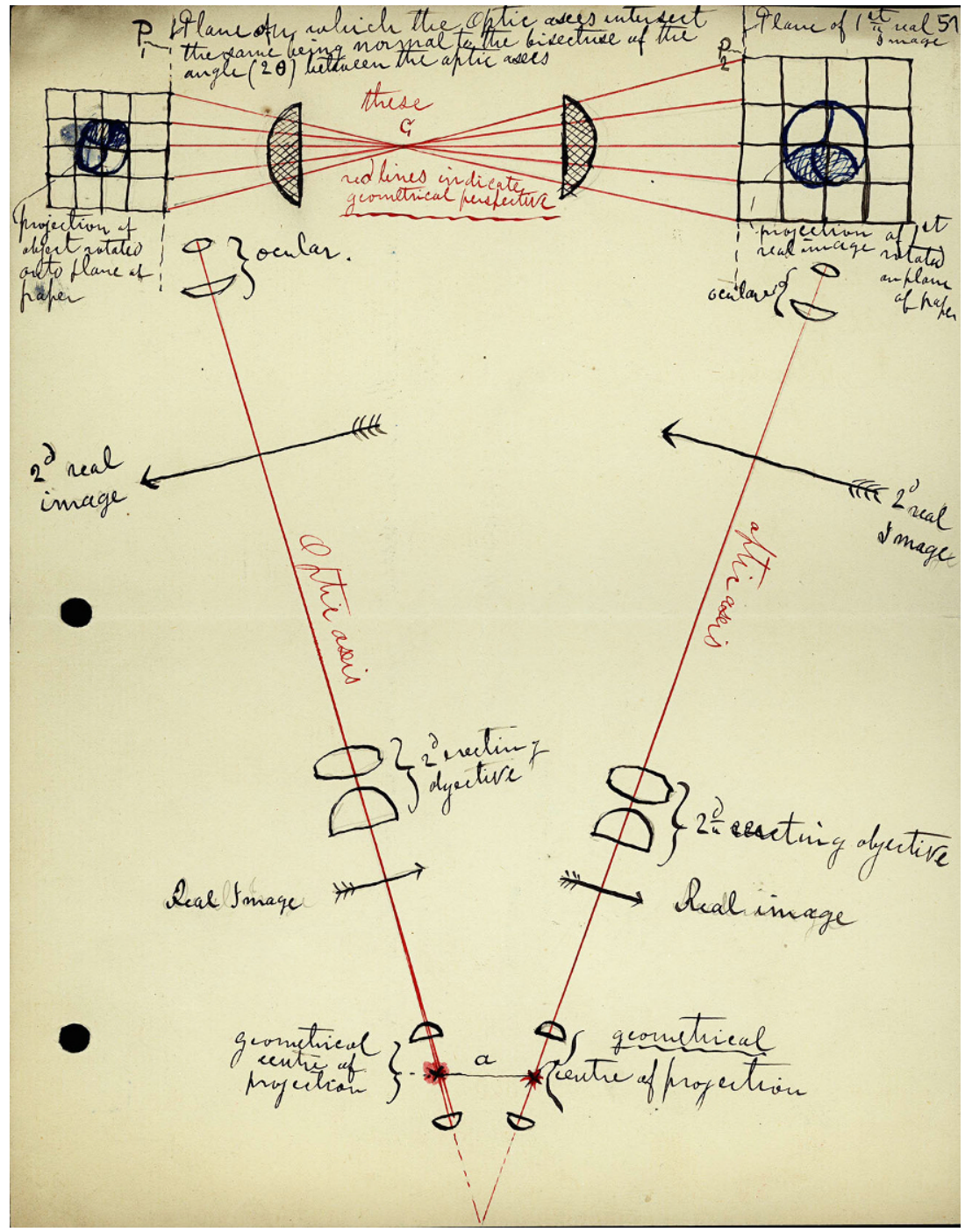

Fig. 4 Greenough updated his design to incorporate several lenses to erect the image. Still, Zeiss used Porro prisms instead (Zeiss Archive (BACZ) 1897-1898: 1579/1)

objective, this was not necessary in Greenough's design. Like d'Orléan's attempt, it separated the light beam mechanically, by using two tubes, each with its own objective. As in nature, the two tubes, tilted at $14^{\circ}$, enclosed the rays of light travelling from an object to the eyes, thereby creating two images, which the human brain fuses into one three-dimensional image. ${ }^{26} \mathrm{He}$ explicitly did not intend for his design to replace the monocular microscope (Gause 1966: 113), since he knew from referring to Ernst 
Abbe's work, that his design would not allow for larger magnifications than 60-120 times (Greiner \& Sander 1987: 166). ${ }^{27}$

With a microscope facilitating a three-dimensional view, Greenough still needed an instrument allowing him to examine a specimen from all sides without having to nudge, turn and thereby possibly destroy a living embryo. Inspired by Louis Chabry's capillaire rotateur, Greenough devised a prism rotator ("Prismenrotator") (Fig. 1), which consisted of a prism onto which the prepared object was placed. Mirrors were positioned around this constellation, reflecting the images projected by the prism of the specimen's sides and underside into the viewers eyes. Whereas Chabry had used mechanical rotating devices based on capillary action, suction, and manual rotation, Greenough had an altogether more sophisticated instrument in mind. ${ }^{28}$

Being on the board of the Zeiss Foundation management since 1891, put Siegfried Czapski in the position to allocate the funds for constructing Greenough's microscope and to reply to Greenough's letter on 27 August 1892, while his superior, Ernst Abbe, was on holiday. Czapski, although he had no idea of Greenough's scientific credentials, replied that they would be willing to build him a stereoscopic microscope. Moreover, he informed Greenough that such binocular stereomicroscopes had in fact been built by Chérubin d'Orléans in 1677 (d'Orléans 1677), and tested by Harting in the middle of the nineteenth century:

Bis Mitte dieses Jahrhunderts [hatte] P. Harting mit einem ähnlich gebauten Instrument Versuche an[ge-]stellt, die aber, wie er glaubt wegen ungenügender Correction der Linsen, unbefriedigende Ergebnisse hatten. Er hatte sein Instrument durch Anwendung eines zweiten Paares von Objektiven hinter den ersten, wie auch Sie es in Ihrem Entwurf vorgesehn haben, unnötig kompliziert. (Czapski in Flitner \& Wittig 2000: 219)

Whether or not Greenough already knew about Cherubin's design is open to speculation but considering his professional academic environment and his elite background it does not seem unlikely. The fact that he did not mention it in his first approach to Zeiss, suggests that he may have been inclined to take credit for the invention himself-an allegation substantiated by the self-righteousness he later displayed regarding his own design. A couple of months later, in 1893, Greenough finally travelled to Jena to meet with Ernst Abbe in what has become a somewhat legendary meeting with cigars being shared in Abbe's front room and a heated discussion about the specifics of the microscope. ${ }^{29}$ 


\section{Porro Prism: Zeiss' Modification}

In his sketch Greenough had used a lens that-he claimed-made sure that the inverted image was reoriented and arrived erect at the eye. This, however, was simply not true as Czapski had repeatedly pointed out in his letters (Letters in BACZ 1892-1896: 1578), and making it work by using two lenses would be a substantial technological challenge. ${ }^{30}$ The Zeiss opticians were not convinced by this concept and argued in favour of the so-called »Porro prism « instead, a considerably more elegant solution to erecting the stereoscopic image. As indicated before, there had always been a potential range of applications for a stereoscopic microscope, even if the life sciences preferred high magnification before the 1880 s and 1890 s. But it was the superior glassmaking and cutting techniques developed in Jena by Schott's glassworks and Zeiss, which ultimately provided an optically tenable answer to stereomicroscopy.

When Abbe tried registering the prisms at the patent office in 1893, he became aware that Ignazio Porro (1801-1875) had already patented the same construction 39 years previously, in 1854. Porro, however, had been unable to produce optical glass in the necessary quality to make the design commercially successful and widely applicable (Gerlach 2009: 751). Otto Schott's Jena glassworks, in contrast, allowed Zeiss to produce »Porro prisms « better than Porro himself (Gerlach 2009: 751). Originally the Porro prisms had been designed for Zeiss' binoculars ("Feldstecher"), for which receiving an upright image and depth perception was also paramount. ${ }^{31}$

In other binocular microscopes the space within the tube would be used not only for magnifying and erecting the image but also for splitting the light beam through optical means, as was the case in Riddell's (1807-1865) build, meaning the light would have to traverse more image correcting glass. But in a design, which mechanically split the beam of light using two separate tubes, that was not necessary. Thus, one Porro prism in each tube reduced the amount of glass a light beam had to penetrate. In this sense, Zeiss insisted, less was more. Besides, the Porro prisms provided two vital advantages over Greenough's design: first, in order to readjust the oculars to the viewers eyes, the Porro prism system only needed to be turned around its own axis, ${ }^{32}$ that is, magnification did not require resetting every time the oculars were adjusted to another viewer. Secondly, the instrument was considerably shorter than Greenough's design allowing dissectors to work for longer periods of time without craning their necks. The Zeiss microscope equipped with Porro prisms corresponded nearly exactly to Greenough's wishes, albeit shifting the resulting image a few millimeters. ${ }^{33}$ A tolerable abstraction-or so Czapski thought. In the letter accompanying the first prototype that the Zeiss workshop had made and 
sent to Greenough's Paris address, he urged Greenough to approach the instrument without prejudice.

Greenough, however, was a perfectionist, who would not take "no" for an answer and tried to convince Czapski, with whom the forthcoming correspondence was principally conducted, to use his lenses instead. His letter from 8 March 1893 maintains that his lenses, "would absorb less light than would the prisms which are otherwise needed to effect the crossing of the objective images" and that using them "will make dissections very much easier" (Greenough 1893 in BACZ 1892-1896: 1578/16), though it is not clear what compelled him to this opinion. The debate continued for years to the point where Greenough virtually forbade Zeiss to use his name for selling the microscope, criticizing that "under these conditions [with Porro prisms] a stereoscopic effect is still had but the instrument no longer merits its name of Orthomorphic Microscope." (Greenough 1897 in BACZ 1897-1907: 1579). ${ }^{34}$ While he had demanded an image that corresponded exactly to the place where the object lay on the dissecting table, the minimal shift of $20 \mathrm{~mm}$ apparently bothered Greenough so much he disinherited his invention completely. In 1902, he even wrote to John Lubbock, 1st Baron Avebury (1834-1913) of the Royal Society in London-carbon copied to Zeiss:

Dear Lord Avebury,

I take the liberty of addressing you [...] I have just taken the following line of action [...] I have withdrawn my former request made to the Carl Zeiss firm of Jena for their scientific co-operation. [...] I have advised them that the business between us must be closed, unless my order for an Orthomorphic Microscope is accepted at once. The Carl Zeiss house are aware that the microscope listed by them under my name meets with my sanction simply because I wish to act in fairness to them; but I have long since informed them that I consider the one they make to be an inefficient makeshift, and that the listing of the same under my name might injure my reputation as a man of science. With the scientific staff of Carl Zeiss firm my relations are most cordial, and there is no difference of opinion between us as to the Geometrical Theory of my proposed Orthomorphic Microscope. (Greenough 1902 in BACZ 1900-1907: 1576/76)

Greenough's correspondence was at times highly antagonistic, even though his furious letters were often followed the next day by apologies for his previous remarks (Sander 1992: 240). Yet Czapski never lost his patience. Regarding the delivery of the stereomicroscope's first prototype on 31 March 1894, he asked Greenough for an unbiased approach: "Ich bitte 
Sie nochmals, die von uns vorgenommenen Abweichungen von Ihrem Plane nicht als eigenmächtig anzusehen, sondern als hervorragend aus unserer besten Überzeugung." (Flitner \& Wittig 2000: 235). Although the initiator of the stereomicroscope never agreed to the final construction plan, Zeiss prevailed:

Die genannte Wirkung wird durch die Combination der Porro'schen Prismen mit dem (bildumkehrenden) zusammengesetzten Mikroskop erreicht, sodass die charakteristischen Vorteile des letzteren vor den sog. Präpariersystemen unverändert erhalten bleiben, sein Hauptnachtheil aber, die Bildumkehrung, wegfällt. Das binoculare stereoskopische Sehen wird nicht durch die nachträgliche Theilung der von einem Objectiv aufgenommenen Strahlenbüschel herbeigeführt, wie bei den anderen stereoskopischen Mikroskopen, sondern es werden zu diesem Zweck 2 vollständige Mikroskope mit je einem Objectiv und einem Okular gleichzeitig auf das Object gerichtet. Diese Construction, welche allein die Möglichkeit stereoskopisch richtiger (orthomorpher) Abbildung gewährt, lässt andererseits nur verhältnismäßig schwache Vergrößerungen zur Anwendung gelangen [...]. (Zeiss 1898)

Zeiss did honor Greenough's wishes and removed his name from the catalogues starting in 1912 (Zeiss 1912), however adding it again to later catalogues following Greenough's death in 1916 at Neuilly in France.

\section{The Stereomicroscope in Experimental Practice}

But even if the instrument was now optically feasible using Porro prisms, what compelled Abbe and Czapski to put up with such a petulant and self-proclaimed scientist, whose concept of a stereoscopic dissecting tool hardly deserved the name microscope, so low was its magnification power? Taking into account that Czapski and Abbe were intimately connected to the university next door, and thus aware of the epistemological shift occurring there, the economic feasibility of an instrument for experimental vivisection now seemed assured. To test whether the instrument would prevail on the scientific marketplace Zeiss introduced the prototype of the stereomicroscope to the life science departments of the university. In 1895 Hermann Braus and Leo Drüner, two anatomy assistants at the university, discussed various experimental proceedings as well as the adequacy of different microscopes including the prototype of the Greenough stereomicroscope in a paper. Their review was supported by the friendly assistance of Zeiss: 
Dadurch, daß wir persönlich mit Vertretern der optischen Werkstätte von C. Zeiss in Verbindung treten konnten und hier das gewohnte liebenswürdige Entgegenkommen in Rat und That fanden, warden unsere Pläne schnell zu einem günstigen Resultat geführt. (Braus \& Drüner 1895: 438)

Two years later, even before Czapski published the scientific theory and technological set-up of the stereomicroscope in 1897, they described their use of the Greenough microscope for scientific research (Czapski 1897). Using the first "Stemi" to prepare finer muscles and nerves as well as to observe organisms in aquaria, they describe its advantages as being so substantial that it had already proven indispensable for such histological proceedings (Braus \& Drüner 1897: 5). It was only after Drüner and Braus had published their positive review of the stereomicroscope's prototype that Zeiss initiated serial production and introduced it into the marketplace of laboratory equipment (Gerlach 2009: 750). Their enthusiastic account forecasts how the microscope extended into the scientific community, where it became a vital part of laboratory practice. Vital, yet secondary. As the stereomicroscope was used for observing, manipulating and dissecting specimens, before potentially interesting stages were fixed and observed under a stronger microscope, historically relevant biological discoveries were, if at all, associated with the monocular microscopes (Sander \& Ohly 1999: 245). The epistemological value of the stereoscopic microscope has hitherto gone mostly unnoticed.

One exception is the experimental embryologist Hans Spemann (1869-1941), who emphasized his scientific and experimental philosophy, and the discipline with which he implemented them. He meticulously recorded his results, the causal analysis from one trial to the next and, significantly, his methods and instruments. In one paper he notes: "Alle diese subtilen Handgriffe wären kaum möglich ohne das schöne Greenough'sche Binokular, das bekanntlich von Braus und Drüner in die Präpariertechnik eingeführt und diesem Zweck angepasst wurde" (Spemann 1906: 197). Like Greenough's, Spemann's first publications are exclusively descriptive, but he was influenced by Roux's experimental inductivism from 1897 onwards, incidentally the same year the stereomicroscope was introduced by Zeiss. From then on, the experiment was, for him, the most important and trustworthy tool to uncover causal links in ontogenetic processes, which he hypothesized based upon previous findings (Fäßler 1997: 115-121). The later Nobel prize laureate conducted fundamental basic research with creative experimental methods, such as lacing off amphibian embryos with hair of his baby daughter to manipulate normal development of amphibian embryos, as well as microsurgical organ transplantations within forming 


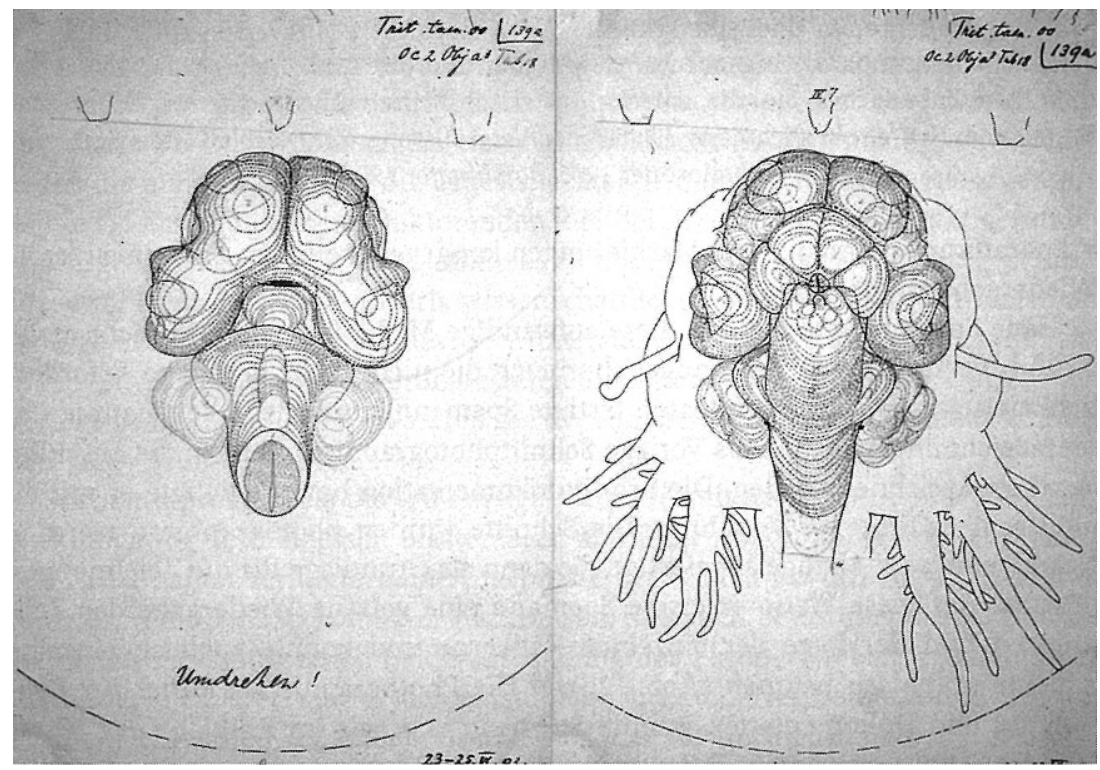

Fig. 5 Stereometric drawings made by Hans Spemann using Kastschenko's neural reconstruction method (Zoologisches Institut Freiburg, Nachlass Hans Spemann, Protokollordner 1900)

embryos. Spemann made detailed drawings of his microscopic labor: using the the neural reconstruction method of Kastschenko, he drew the contour lines of each microtome cut from a series, which, when put together, yielded a complete, stereometric image not unlike His' microtome modelling (Fäßler 1997: 141). This cartographic representation, with lines indicating specific elevations, produced images of developing embryos that imitated three-dimensionality (Fig. 5).

Such experiments might lead to the assumption that Spemann, like Roux or His, must also have adhered to the mechanical philosophy inherited from physiology. A misconception, however, since Spemann combined within his person a pragmatic mechanical approach with a more holistic conception of the functioning of the embryo as a whole (Allen 2005). Though the new generation of experimental biologists shunned holistic views as vitalist, or even supernatural; others regarded a reduction of a system into its interacting physiochemical mechanisms as too simplistic. "So what", as Allen has remarked, "if ions in solution in the cell cytoplasm, or in blood plasma obeyed Arrhenius's laws of electrolytic dissociation. That was not what made an organism 'alive"' (Allen 2005: 275). Spemann's research, in contrast, was not concerned with the molecular mechanics in fertilized eggs, but on a higher level of organization. At tissue-level the embryo appeared to him as a "harmonious equipotential system", a term he 
appropriated from his colleague Hans Driesch (1867-1941), who later lost his scientific position due to his outright vitalist ideas. Spemann, however, was not a vitalist. But he was convinced that some processes could only be understood or were only interesting at tissue-level, and that reduced to the physiochemical level they would lose their essence (Allen 2005: 275). Spemann reflected on his experimental epistemology in later years:

Als Vorbild schwebt mir dabei die Arbeitsweise des Archäologen vor, der aus den Bruchstücken, die allein er in den Händen hält, ein Götterbild wieder zusammenfügt. Er muß an das Ganze glauben, das er nicht kennt; aber er darf nicht nach eigenen Gedanken gestalten. Er muß selbst soweit Künstler sein, daß er den Plan des hohen Meisters schrittweise nachschaffen kann, aber sein oberstes Gebot ist, die Bruchflächen heilig zu halten. Nur so darf er hoffen, neue Funde an ihrem richtigen Orte sicher einfügen zu können. (Spemann 1936: 274-275) ${ }^{35}$

Good experimental practice, for him, was to strike a balance between denying the temptation of forcing results into grand narratives, such as Darwinian evolution, and appreciating that organisms do function as interacting systems not all reducible to the physiochemical. The gaps left in mechanical reasoning may not be filled by invoking supernatural forces; one must keep the fractures holy. In order to understand the interaction of developing tissues and the causation behind them, it was important to appreciate the "wholeness of the organic process, to interact with the organism on its own terms and not a mosaic of its parts" (Allen 2005: 275). Though the life sciences had throughout Greenough's and Spemann's careers come a long way in reintroducing nature's complexity and messiness into the lab, theorizing was the terrain of abstraction in physiochemical terms. And rightly so. But Spemann, who evidently recognized the importance of understanding the embryo as a whole, also understood that such mechanical holism demanded visual holism too; a mode of representation that would do the "harmonious equipotential system" justice.

He might have taken up modelling, like his predecessor Wilhelm His, to "give body" to his views (Hopwood 1999), but on the brink of the twentieth century wax reconstructions were set aside as being too static to adequately represent the cascade of developmental processes that transformed a bundle of cells into a living being. A mode of representation was needed that would not only show the whole, living embryo, not only sectioned parts of it, but also reflect the dynamism and interactive nature of embryogenesis. Thankfully, Zeiss had just introduced such an instrument. 


\section{Three-dimensional Microscopy and the Ideals of the new Life Sciences}

After Darwin's Origin of Species had constructed an all-encompassing view of nature, many scientists gravitated towards methods and questions concerning evolution, while fewer were concerned with the physiological function and causation of phenomena in their own right. The Darwinian wave broke slowly and then crashed during the 1880s and 1890s with the works of Chabry in France but, most prominently, in Germany with Wilhelm His, Wilhelm Roux and later Hans Spemann. Throughout Horatio S. Greenough's trajectory from an interested layman to a natural historian to a somewhat untalented experimental embryologist, we can appreciate the historical and epistemological upheaval of the life sciences that Greenough and Chabry were navigating and participating in at Concarneau. Their eagerness to experiment with live organisms, to appreciate its entire shape, and its mutually interacting tissues, was vitally important for this new generation of experimental zoologists. Zeiss was sensitive to these developments and, with their optical expertise, reacted accordingly. In the following years the stereomicroscope entered the biological laboratory and became a vital instrument in experimental practice, allowing scientists to manually handle their specimens in hitherto unimagined dexterity.

However, the stereomicroscope not only enabled scientists manually, thus resulting from and furthering the new experimental ideal. It also enabled them visually. In parallel to a rejuvenation of the sphere as ideal representative of holistic nature a new sense of objectivity, a scientific morality that condemned the subjectivity of the not-to-be-trusted human senses, developed in the late nineteenth century (Daston \& Galison 2007). Manual manipulation of the scientific object, such as elaborate preparation practices, was ideally kept to a minimum to let nature emerge as a mechanical imprint of life itself, unobstructed by subjective human theories and aesthetic preferences-an ideal clearly catered for by the stereomicroscope. This development is parallel to the reintroduction of life into the laboratory which sought to naturalize the image of nature constructed within. The term "image of nature" is not merely a metaphor for the knowledge generated in the spaces of experimental practice, but can, and should be taken literally to describe the imagery created by science. Experimentation entailed a mechanistic abstraction of life to its physiochemical processes, staging natural environments and phenomena and codifying observation in numbers, formulas and graphs. Though the stereomicroscope facilitated this experimental ideal, it, in contrast, yielded imagery that presented nature as a whole, living, interacting system of tissues-a naturalistic, threedimensional organism, an idealized primordial sphere. Thus, the devel- 
opment of the experimental method in the life sciences, which abstracts from nature in turn generated imagery that returned to nature. Mechanistic experimental practice and a holistic visual understanding of natural processes as a whole could be united in the stereomicroscope, an objective Hans Spemann presumably appreciated (Fäßler 1997: 115-121). Mechanical reduction through experimentation apparently no longer missed out on understanding nature as a whole. It seems that imagery that looked, felt and was considered "natural" could compensate for an experimental reality that was not. The stereomicroscope thus entered scientific reasoning not simply as a practical facilitator, but also as a thinking medium for understanding the organism and its life processes in their entirety. Image and imagination of nature through science, then, are profoundly interconnected by their shared epistemological ideals. ${ }^{36}$

\section{Acknowledgements}

For introducing me to this surprisingly fascinating instrument at a workshop held at the Deutsches Museum Munich, I must thank Prof. Dr. Richard Kremer, Prof. Dr. Peter Heering, Dr. Christian Forstner and Dr. Johannes-Geert Hartmann. Furthermore, I am deeply grateful for the help of Wolfgang Wimmer at the Zeiss archive, Bernd-Joachim Lau and Dr. KarlPeter Ohly for providing me with vital information on Greenough and his scientific credentials. Many thanks are due also to Dr. Mathias Grote at the Humboldt Universität Berlin for taking time to read and discuss this paper with a somewhat overzealous master's student he hardly knew.

\section{Endnotes}

1 I am deeply indebted to Christian Reiß' insightful paper on the history and epistemology of the aquarium for inspiring these opening remarks referencing Edgerton's and Espahangizi's work (Reiß 2012).

2 For a traditional outlook on the situation of the life sciences around 1900 see Allen (1971); and Coleman (1977), especially the chapter The Experimental Ideal. For a more distinguished, updated take on the epistemic and methodological shift see Nyhart (1987); Nyhart (1996); Jahn (2004); Nyhart (2009); and Hopwood (2011).

3 Richard Hertwig laments, that "[wir erleben] auf dem Gebiet der Zoologie den Ansturm einer jugendlichen Forschungsrichtung, welche für sich allein das Privileg der Wissenschaftlichkeit in Anspruch nimmt und der alten Forschungsweise eine sehr minderwertige Stellung einräumt." (Jahn 2004: 429).

4 Garland Allen's Life Sciences in the Twentieth Century and especially a paper written by him on the same subject sparked considerable backlash in the Journal of the History of Biology, when Jane Maienschein, Ronald Rainger, and Keith Benson criticised several 
points Allen had made, chiefly his evaluation of the turn towards experimentation to be a revolution, instead of an evolution (Allen 1981).

5 Intervention into the living organism was especially easy in aquatic invertebrates, as their systems are substantially simpler than vertebrates', making it easier to interfere in their development (Hopwood 2011). The dynamic nature of embryologists' object of inquiry, its relatively small size, and the fact that growth takes places in the open water naturally as opposed to within a mother animal were ideal conditions for experimental investigations (Hopwood 1999: 493).

6 On Abbe and his scientific work for Zeiss, Semel (2014); Buenstorf \& Murman (2005); Gerth \& Wimmer (2005); Lemuth \& Sturz (2005). Zeiss' interaction with the university, especially via the Carl Zeiss Foundation is the focus of Steinbach \& Demel (2014); Matthes (2013). A comprehensive yet not up to date bibliography is found on the website of the Zeiss cooperation under the heading of the archive.

7 Concerning the chemical expertise of Otto Schott and his cooperation with the optical workshop of Carl Zeiss, Steiner (2000), Steiner (2001), Steiner \& Hoff (1995) and the textbook on glass chemistry by a former professor at the Otto Schott Institute, Vogel (1994).

8 Gause in his extensive work on the history of microscopy briefly outlined what is known from the Zeiss archives, Klaus Sander built on this, and finally Berndt-Joachim Lau, a former Zeiss employee, together with the microscopist Jordan Kreindler went to great lengths to unearth information in the state and university archives in the United States, and the family records of the eighteenth and nineteenth century Boston family of Greenough. Some of the sources are not published by scholars and have not been subjected to the rigorous citation system historians are used to. Where the information is not verifiable, it has been noted (Gause 1963; Sander 1992; Lau \& Kreindler 2018).

9 The Greenough family lived in Europe until Greenough Jr. was six years old. Writing from the Graefenberg sanatorium in Austrian Silesia, today's Czech Republic, he recorded that his wife Louisa (Eliza) Ingersoll Gore bore their only son on 11 May 1845 (Lau \& Kreindler 2018: 14; Wright 1972). Originally from Boston, the couple had been living in Florence previously, travelling and studying antique and renaissance art. Both their families appear to have been well situated, and the couple led a life of upper middle-class professionals, Horatio as an artist and Eliza as a fundraiser for the Mount Vernon Ladies Association (Mount Vernon Ladies' Association of the Union 1953).

10 Documents from the Bundesarchiv Carl Zeiss will henceforth be referred to thus: BACZ followed by 1578, 1579 or 1576 specifying the box and, if labelled, a number.

$11 \mathrm{He}$ is documented to have been a year three "special" student for the semester 1866-1867 in the archives of the Massachusetts Institute for Technology, MIT. The term suggests he was free to choose courses at will. Information shared with Lau and Kreindler via email in 2016. This information is not completely verifiable (Lau \& Kreindler 2018).

12 From the records of the Bulletin de la Société zoologique de France and the correspondence with the Zeiss company it is clear that Greenough resided primarily in Paris, for many years at Rue de Bassano 30, which today houses a luxury hotel, but even then must have been a rather fashionable address (Société zoologique de France 1891: XI).

13 Greenough had been studying the growth and development of young hummingbirds when he published his first article in a scientific journal: The American Naturalist, in 1886 , a document which has gone unnoticed by any previous scholars. The entire fourpage paper is descriptive, as was common practice for zoologists in the nineteenth century, but it seems that Greenough was at the time more of an interested layman and indeed did not have much experience as a scientist yet. For example, he might have compared the hummingbird development to that of other birds, might have discussed the shape of their beaks in relation to their feeding habits (in true Darwinian style), or might have referenced other scientists, who no doubt had also been studying the early life of birds in North America (Greenough 1886). 
14 Previous scholars have speculated on the exact dates of his visits or stay at Concarneau, Sander providing a visitor record from 1889, and the letter from Greenough to Abbe in 1892, was also sent from Concarneau. Based on my findings, Greenough was actually at Concarneau as early as 1887, as he is listed in the yearbook as a research student of the histological laboratory for the years of 1887 and 1888 (Pouchet 1886: 98).

15 Unfortunately, the last page of this text is missing in the book and Karl Peter Ohly was so kind as to provide the missing sentences.

16 He confirms that while in the early stages of invertebrate development the blastopore, the first opening in a blastula, turns into the later mouth, in vertebrates (such as frogs) this primary structure turns into the anus. Thus, there is a homology between the dorsal (back) and ventral (front) sides of embryo' across taxonomic groups. From this he posits that the spinal-cord of vertebrates is homologous to the ventral nerve chord of invertebrates (Greenough 1892: 57-59). One might have gone further to posit a phylogenetic relationship, as Sander and Ohly have pointed out (Sander \& Ohly 1999: 247-248).

17 "Gastrulation beim Frosch - einem damals weitgehend fehlgedeuteten Vorgang," (Sander \& Ohly 1999: 247).

18 Sander reduces the meaning of mechanics to make his point, however, the definitions of the word oscillated between actually mechanistic and the opposite of supernatural (Sander 1997: 2; Mayr 1904: 155).

19 In his sketches Leonardo da Vinci examines the projections to each eye of a small sphere and its background, which could be seen with both eyes open but not with one (Wade \& Ono 2012: 55).

20 The stereoscope presents the eyes with the reflections of two perspectival sketches of a geometric object. The left eye looks into the left mirror and the right eye into the right mirror. The corresponding points of the sketch would be reflected through the mirror and unified in the viewer's brain appear three dimensional. The instrument itself is epistemologically significant, because as Wade has put forward in several of his publications, the stereoscope did for spatial vision, what Newton had done for colour vision: "Newton's decomposition of white light into its spectral components removed the perception of color from the coloured objects that naturally conveyed it." Likewise, Wheatstone achieved a fragmentation of the components of depth perception from each other (left and right retinal projections), as well as from the object that projected the images (Wade \& Ono 2012: 54).

21 Pieter Harting made no advances in the design of the d'Orleans' microscope model but reconstructed and described it (Harting 1859: 242-243; Gerlach 2009: 738).

22 The fragmentation of the light beam in the rear part of the focal plane meant that the field of view would be small and unevenly illuminated with large magnifications (Gerlach 2009: 741).

23 Abbe himself conceived a stereoscopic ocular in 1880, but if was not well received by the scientific community.

24 The sketch is from a later letter than the original, as the latter was lost. However, the sketch accompanied in BACZ (1897-1898: 1579/1) shows the identical set-up.

25 Punctuation from the original. Greenough in a letter to Siegfried Czapski, Paris, 7 October 1896. (BACZ 1897-1898: 1579/1).

26 Greenough specified that he wished for magnifications between 20 and 30 times, as his friend Prof. Whitman had used (Greenough 1892 in BACZ 1892-1896: 1578/2), whom he had presumably met while the latter was employed at Agassiz's Museum of Comparative Zoology, which Greenough's uncle had helped build (Cambridge Historical Society 1973: 52-65). Zeiss' realization of Greenough's design would achieve magnifications of 25-40 times, by exchanging the magnifying objectives (Gerlach 2009: 752).

27 „[D]ie förderliche“ Vergrößerung des Geräts [ist] schon durch seinen Aufbau als konvergierendes Doppelmikroskop begrenzt: der Öffnungswinkel jedes der beiden Objektive kann den Konvergenzwinkel der Tuben nicht überschreiten. Dem ursprünglichen Winkel von $14^{\circ}$ entspricht eine numerische Apertur von weniger als 0,12 , so daß die 
förderliche Gesamtvergrößerung zwischen 60- und 120-fach endet (Greiner \& Sander 1987: 166).

28 Zeiss even produced a "Capillar-Rotator" of Laurent Chabry's design in association with the Greenough stereomicroscope (Gerlach 2009: 752).

29 Though upon speaking personally to Zeiss staff, they admit this account might have been embellished for narrative effect. Personal communication with Zeiss staff upon visiting in the Betriebsarchiv Carl Zeiss, 13th March 2018.

30 "Mit erheblichen Schwierigkeiten verbunden" (Czapski 1897: BACZ 1579/11).

31 The two adjoining prisms erect and revert the image, correcting the flipped and inverted image produced by the objective lenses at the tip of the microscope. The blocks of glass are shaped like right-angled triangles, through which the incoming light would be reflected twice on the sloped faces, on each side of the right angle, exiting through the same face it came in through, before being reflected twice again in the adjoining prism.

32 This happens automatically, as the oculars sit on a wider cylinder, which when turned outwards increases the distance of the ocular, when turned inwards decreases the distance of the oculars. This way the magnification level remains undisturbed.

33 The use of the Porro prism shifts the image by $20 \mathrm{~mm}$, which apparently does not impede manipulation (Gerlach 2009: 751)

34 Emphasis in the the original (Greenough 1897 in BACZ 1897-1898: 1579).

35 Emphasis by the author. Spemann (1936: 274-275).

36 Ludwik Fleck's epistemology builds on this entanglement between how we realize things visually, "Gestaltsehen", and scientifically in a specific "Denkstil" (Fleck 1980).

\section{References}

Abbe, Ernst 1873. Beiträge zur Theorie des Mikroskops und der mikroskopischen Wahrnehmung. Archiv für mikroskopische Anatomie (9): 413-468.

Abbe, Ernst 1880. Beschreibung eines neuen stereoskopischen Okulars nebst allgemeinen Bemerkungen über die Bedingungen mikro-stereoskopischer Beobachtung. In: Ernst Abbe 1904. Gesammelte Abhandlungen von Ernst Abbe, Band 3, Gustav Fischer: Jena.

Agassiz, Elizabeth Cabot Cary 1893. Louis Agassiz-His Life and Correspondence. Boston, New York: Houghton, Mifflin \& Co.

Allen, Garland 1981. Morphology and the Twentieth Century. Journal of the History of Biology (14/1): 159-176.

Allen, Garland 2005. Mechanism, Vitalism and Organicism in late Nineteenth and Twentieth-century Biology: The Importance of Historical Context. Studies in History and Philosophy of Biological and Biomedical Sciences (36): 261-283.

Allen, Garland E. 1971. Life Science in the Twentieth Century. Cambridge: Cambridge University Press.

Boston Society for Natural History, 1872. Proceedings of the Boston Society for Natural History (15): 173-175.

Braus, Hermann and Leo Drüner 1895. Ueber ein neues Präpariermikroskop und über eine Methode grössere Tiere in toto histologisch zu konservieren. Jenaische Zeitschrift für Naturwissenschaft (29): 435-442.

Braus, Hermann und Leo Drüner 1897. Das binokuläre Präparier- und Horizontalmikroskop. Zeitschrift für wissenschaftliche Mikroskopie (14): 5-10.

Buenstorf, Guid and Johan Peter Murman 2005. Ernst Abbe's Scientific Management: Theoretical Insights from a Nineteenth-Century Dynamic Capabilities Approach. In: Industrial and Corporate Change (14/4): 543-578.

Cahan, David 1989. An Institute for an Empire. The Physikalisch-Technische Reichsanstalt. 1871-1918. Cambridge: Cambridge University Press. 
Cambridge Historical Society 1973. The Proceedings of the Cambridge Historical Society (43): 52-65.

Carl Zeiss AG 2005. Stazione Zoologica Anton Dohrn, Neapel. Innovation (15): 26-29.

Chabry, Laurent 1887. Embryologie normale et tératologique des Ascidies simples. Paris: Felix Alcan.

Coleman, William 1977. Biology in the Nineteenth Century: Problems of Form, Function and Transformation. Cambridge: Cambridge University Press.

Czapski, Siegfried 1897. Das Stereoskopische Mikroskop nach Greenough und seine Nebenapparate. Zeitschrift für wissenschaftliche Mikroskopie und mikroskopische Technik (14/3): 289-312.

Darwin, Charles 1988. The Works of Charles Darwin. Vol. 15: On the Origin of Species, 1859. London: Pickering.

Daston, Loraine and Peter Galison 1992. The Image of Objectivity. Representations (40): 81-128.

Daston, Loraine and Peter Galison 2007. Objectivity. Cambridge, MA: MIT Press.

Edgerton, David 2007. The Shock of the Old. Technology and Global History since 1900. Oxford: Oxford University Press.

Edwards, Paul N. 2003. Infrastructure and Modernity. Force, Time, and Social Organization in the History of Sociotechnical Systems. In: Thomas J. Misa, Philip Brey and Andrew Feenberg (eds.). Modernity and Technology. Cambridge: MIT Press: 185-225.

Espahangizi, Kijan, 2011. The Twofold History of Laboratory Glassware. In: Mathias Grote, Max Stadler and Laura Otis (eds.). Membranes, Surfaces and Boundaries. Interstices in the History of Science, Technology and Culture. Berlin: Preprints of Max Planck Institute for the History of Science: 17-33.

Fäßler, Peter E. 1997. Hans Spemann 1869-1941. Experimentelle Forschung im Spannungsfeld von Empirie und Theorie. Ein Beitrag zur Geschichte der Entwicklungsphysiologie zu Beginn des 20. Jahrhunderts. Berlin: Springer.

Fischer, Jean-Louis 1991. Laurent Chabry and the Beginnings of Experimental Embryology in France. In: Scott F. Gilbert (ed.). Developmental Biology, vol. 7: A Conceptual History of Modern Embryology. New York: Springer: 31-41.

Fleck, Ludwik 1980. Entstehung und Entwicklung einer wissenschaftlichen Tatsache. Einführung in die Lehre vom Denkstil und Denkkollektiv. Mit einer Einleitung hrsg. von Lothar Schäfer und Thomas Schnelle. Frankfurt a. M.: Suhrkamp.

Flitner, Andreas and Joachim Wittig (eds.). 2000. Optik - Technik - Soziale Kultur. Siegfried Czapski, Weggefährte und Nachfolger Ernst Abbes. Briefe, Schriften, Dokumente. Rudolstadt: Hain Verlag.

Gause, H. 1966. Siegfried Czapski. 1861-1907. In: Hugo Freund (ed.). Geschichte der Mikroskopie. Vol. III. Frankfurt a. M.: Umschau Verlag.

Gehler, Johann Samuel Traugott 1787. Physikalisches Wörterbuch, oder, Versuch einer Erklärung der vornehmsten Begriffe und Kunstwörter der Naturlehre, mit kurzen Nachrichten von der Geschichte der Erfindungen und Beschreibungen der Werkzeuge begleitet in alphabetischer Ordnung. Leipzig: Schwickert.

Gerlach, Dieter 2009. Geschichte der Mikroskopie. Frankfurt a. M.: Verlag Harry Deutsch.

Gerth, Kerstin and Wolfgang Wimmer 2005. Ernst Abbe. Wissenschaftler, Unternehmer, Sozialreformer. Jena: Bussert und Stadeler.

Gould, Stephen Jay 1977. Ontogeny and Phylogeny. Cambridge (MA): The Belknap press of Harvard University Press.

Greenough, Horatio Saltonstall 1886. Observations on Young Hummingbirds. The American Naturalist (20/6): 528-532.

Greenough, Horatio Saltonstall 1891. Observations sur les larves d'oursin. Bulletin de la Société zoologique de France. Pour l'année 1891 (16): 239.

Greenough, Horatio Saltonstall 1892. Sur les homologies des premières stades suivant la segmentation chez les batraciens. Bulletin de la Société zoologique de France. Pour l'année 1892 (17): 57-59.

Greiner, Kurt and Klaus Sander 1987. Das Stereomikroskop - Ursprünge und geschichtliche Entwicklung. Biologie in unserer Zeit (17/6): 161-168.

Harting, Pieter 1859. Das Mikroskop. Braunschweig: Vieweg und Sohn. 
Hopwood, Nick 1999. "Giving Body" to Embryos: Modeling, Mechanism, and the Microtome in Late Nineteenth-Century Anatomy. Isis (90/3): 462-496.

Hopwood, Nick 2011. Approaches and Species in the History of Vertebrate Embryology. In: Francisco J. Pelegrini (ed.). Vertebrate Embryogenesis. Embryological, Cellular and Genetic Methods. New York: Humana Press: 1-20.

Jahn, Ilse (ed.). 2004. Geschichte der Biologie. Hamburg: Nikol.

Kleeberg, Bernhard 2005. Theophysis. Ernst Haeckels Philosophie des Naturganzen. Köln: Böhlau Verlag.

Kleeberg, Bernhard 2007. Ideal (Geometrical) Types and Epistemologies of Morphology. In: Erna Fiorentini (ed.). Observing Nature-Representing Experience. The Osmotic Dynamics of Romanticism 1800-1850. Berlin: Reimer: 187-203.

Kohler, Robert E. 2002. Labscapes: Naturalizing the Lab. History of Science (40): 473-501.

Lau, Berndt-Joachim and Jordan R. Kreindler/Microscopy-UK. Who was Horatio Saltonstall Greenough? Pt. II. URL: http://www.microscopy-uk.org.uk/mag/artjan19/rjk-bjl-HSG2.pdf, January 2019, accessed 24th January 2019.

Lau, Berndt-Joachim and Jordan R. Kreindler/Microscopy-UK. Who was Horatio Saltonstall Greenough? Pt. I.URL: http://www.microscopy-uk.org.uk/mag/indexmag.html, February 2018, accessed 15th March 2018.

Lemuth, Oliver and Rüdiger Sturz 2005. Wissenschaftsbasierte Optik und unternehmerische Vernunft. Zum 100. Todestag Ernst Abbes. Physik Journal (4/1): 37-41.

Marey, Étienne-Jules 1878. La méthode graphique dans les sciences experimentales et principalement en physiologie et en médecine. Paris: Masson.

Matthes, Christoph 2013. Finanzier - Förderer - Vertragspartner. Die Universität Jena und die optische Industrie 1886-1971. Weimar: Böhlau Verlag.

Mayall, John 1886. Cantor Lectures. The Microscope. Modern Microscopes to the Date of the Application of Achromatism. Journal of the Society of the Arts (34): 1007-1021.

Mayr, Ernst 1904. The Growth of Biological Thought. Diversity, Evolution, and Inheritance. Cambridge (MA): Harvard University Press.

Mount Vernon Ladies Association of the Union 1953. Catalogue of the Centennial Exhibition Commemorating the Founding of the Mount Vernon Ladies Association of the Union: 1853-1953. Detroit: University of Michigan.

Nyhart, Lynn K. 1987. The Disciplinary Breakdown of German Morphology. Isis (78): 365-389.

Nyhart, Lynn K. 1995. Biology Takes Form. Animal Morphology and the German Universities 1800-1900. Chicago: Chicago University Press.

Nyhart, Lynn K. 1996. Natural History and the "New Biology". In: N. Jardine, J.A. Secord and E.C. Spary (eds.). Cultures of Natural History. Cambridge: Cambridge University Press: 426-443.

Nyhart, Lynn K. 2002. Learning from History: Morphology's Challenges in Germany ca. 1900. Journal of Morphology (252): 2-14.

Nyhart, Lynn K. 2009. Embryology and Morphology. In: Michael Ruse and Robert J. Richards (eds.). The Cambridge Companion to the 'Origin of Species.' Cambridge: Cambridge University Press: 194-215.

d'Orléans, Chérubin 1677. La dioptrique oculaire ou la théorique, la positive, et la méchanique, de l'oculaire dioptrique en toutes ses espèces. Paris: S. Mabre-Cramoisy.

Pellerin, Danis and Brain May 2014. The Poor Man's Picture Gallery: Stereoscopy versus Paintings in the Victorian Era. London: The London Stereoscopic Company.

Pouchet, Georges 1886. Laboratoire d'histologie zoologique (année 1887). In: Rapport sur l'École pratique des hautes études, 1886-1887. Paris: École pratique des hautes études.

Reiß, Christian 2012. Gateway, Instrument, Environment. The Aquarium as a Hybrid Space between Animal Fancying and Experimental Zoology. NTM (20): 309-336.

Rheinberger, Hans-Jörg 2008. Intersections: Some Thoughts on Instruments and Objects in the Experimental Context of the Life Sciences. In: Helgar Schramm, Ludger Schwarte and Jan Lazardig (eds.). Instruments in Art and Science: On the Architectonics of Cultural Boundaries in the 17th Century. Berlin: Walter de Gryuter: 1-19.

Russel, Edward S. 1916. Form and Function. A Contribution to the History of Animal Morphology. J. Murray: London. 
Sander, Klaus 1992. An American in Paris and the Origins of the Stereomicroscope. Roux's Archives of Developmental Biology (202): 235-242.

Sander, Klaus 1997. Wilhelm Roux and His Programme for Developmental Biology. In: Landmarks of Developmental Biology. 1883-1924. Historical Essays from Roux's Archives. Berlin: Springer: $1-3$.

Sander, Klaus and Jean-Louis Fischer 1992. How to Dart Ascidian Blastomeres: The Embryological Micro-tools of Laurent Chabry. In: Klaus Sander (ed.). Roux's Archive of Developmental Biology (201): 191-193.

Sander, Klaus and Karl Peter Ohly 1999. Horatio S. Greenough, Initiator des Stereomikroskops. In: Armin Geus, Thomas Juncker, Hans-Jörg Rheinberger, Christa Riedle-Dohrn and Michael Weingarten (eds.). Repräsentationsformen in den biologischen Wissenschaften. Beiträge zur 5. Jahrestagung der DGGTB in Wien 1996 und zur 7. Jahrestagung in Neuburg a. d. Donau 1998. Berlin: VWB-Verlag: 245-248.

Semel, Sebastian 2014. Auf dem Weg zur Verantwortungsgesellschaft: Ernst Abbe und die Carl-Zeiss-Stiftung im deutschen Kaiserreich. Göttingen: Wallstein.

Société zoologique de France 1891. Liste de membres de la société. Bulletin de la Société zoologique de France. Pour l'année 1888 (13): XI.

Spemann, Hans 1906. Über eine neue Methode der embryonalen Transplantation. Verhandlungen der Deutschen Zoologischen Gesellschaft (16): 195-202.

Spemann, Hans 1936. Experimentelle Beiträge zu einer Theorie der Entwicklung. Berlin: Verlag Julius Springer.

Steinbach, Peter and Sebastian Demel 2014. Ernst Abbe und die Gründung der Carl-ZeissStiftung. Wissenschaftsförderung - Gestaltungswille - Verantwortung. In: Werner Plumpe (ed.). Eine Vision. Zwei Unternehmen. 125 Jahre Carl-Zeiss-Stiftung. München: C. H. Beck: 29-55.

Steiner, Jürgen 2000. Otto Schott und die Erfindung des Borosilicatglases. Jenaer Jahrbuch zur Technik- und Industriegeschichte (2): 7-23.

Steiner, Jürgen 2001. Otto Schott - Wissenschaftler, Technologe, Unternehmer mit gesellschaftlicher Verantwortung. Biographische Facetten zum 150. Geburtstag. Jenaer Jahrbuch zur Technik- und Industriegeschichte (3): 7-26.

Steiner, Jürgen and Uta Hoff 1995. Das Jenaer Glaswerk 1884-1934. In: Jürgen John and Volker Wahl (eds.). Zwischen Konvention und Avantgarde. Doppelstadt Jena-Weimar. Weimar, Köln: Böhlau Verlag: 209-232.

Uschmann, Georg 1983. Ernst Haeckel. Biografie in Briefen. Leipzig: Urania.

Vogel, Werner 1994. Glass Chemistry. 2nd edition, Berlin: Springer.

Wade, Nicholas J. and Hiroshi Ono 2012. Early Studies of Binocular and Stereoscopic Vision. Japanese Psychological Research (54/1): 55-68.

West, Charles E. 1891. The Binocular Microscope of the Seventeenth Century. In: Proceedings of the American Society of Microscopists. Thirteenth Annual Meeting, held at Detroit, Mich., Aug. 12, 13, 14, and 15, 1890. Washington, D.C.: Judd \& Detweiler: 57-66.

Wheatstone, Charles 1838. Contributions to the Physiology of Vision-Part the first. On some Remarkable, and hitherto Unobserved, Phenomena of Binocular Vision. Philosophical Transactions of the Royal Society (128): 372-373.

Wimmer, Wolfgang 2005. Das Verhältnis von Carl-Zeiss-Stiftung und Zeisswerk zur Universität bis 1933. In: Matthias Steinbach and Stefan Gerber (eds.). "Klassische Universität" und "akademische Provinz". Studien zur Universität Jena von der Mitte des 19. bis in die dreißiger Jahre des 20. Jahrhunderts. Jena/Quedlinburg: Dr. Busserl \& Stadler: 59-76.

Wright, Nathalia 1963. Horatio Greenough: The First American Sculptor. Philadelphia: University of Pennsylvania Press.

Wright, Nathalia 1972: Letters of Horatio Greenough-American Sculptor. Madison: The University of Wisconsin Press.

Zeiss 1898. Mikroskope und Mikroskopische Hilfsapparate, Zeiss Katalog. Jena: Bernhard Vopelius.

Zeiss 1912. Mikroskope und Mikroskopische Hilfsapparate, Zeiss Katalog. Jena: Bernhard Vopelius.

Zeiss 1927. Mikroskope und Mikroskopische Hilfsapparate, Zeiss Katalog. Jena: Bernhard Vopelius. 
Publisher's Note Springer Nature remains neutral with regard to jurisdictional claims in published maps and institutional affiliations.

\author{
Anna Simon-Stickley \\ Technische Universität Berlin \\ Straße des 17. Juni 135 \\ 10623 Berlin \\ Germany \\ a.sim.stick@gmail.com
}

